DOI: https://doi.org/10.32839/2304-5809/2021-6-94-22

UDC 620.97:697.329

Kasynets Mariana, Kuznetsova Marta, Sukholova Iryna, Datsko Oleksandra National University "Lviv Polytechnic"

\title{
IMPROVING THE EFFICIENCY OF THE SYSTEM WITH SOLAR COLLECTORS
}

Summary. The paper solves an important issue of the efficiency of two collectors that have different orientations at different angles of incidence of solar radiation intensity. That is why the paper carries out a wide-parameter study of their thermal engineering characteristics. It is investigated that the change in the azimuth angle a from $90^{\circ}$ to $60^{\circ}$, under the $\varphi=90^{\circ}$ does not significantly affect the efficiency of the system with solar collectors, and its further deviation significantly reduces. It is also established that the simultaneous deviation of angles a and $\varphi$ leads to a significant reduction in the use of the incident intensity of solar radiation on the solar collector and the efficiency of the system with solar collectors in general. As a result of theoretical calculations its average annual value is obtained $\bar{K}_{\text {eff }}$, accordingly for a different number of discrete collector orientations $N$.

Keywords: solar energy, solar radiation, solar collector, discrete orientation, heat carrier temperature, heat supply.

Касинець М.Є., Кузнєцова М.Я., Сухолова I.Є., Дацько О.С.

Національний університет «Львівська політехніка»

\section{ПІДВИЩЕННЯ ЕФЕКТИВНОСТІ СИСТЕМИ ІЗ СОНЯЧНИМИ КОЛЕКТОРАМИ}

Анотація. Актуальним питанням сьогодення залишається перетворення сонячної енергії в теплову та електричну. Встановлено, що без екологічної шкоди можна використати $\approx 15 \%$ всіеї сонячної енергії. Кількість сонячної енергії в Україні, що поступає на одиницю площі протягом року складає $1000-1350$ кВт тод/м². Поряд із цим, для перетворення сонячної енергії розробляють все більше установок, що потребують постійного вдосконалення зважаючи на темпи розвитку сонячної енергетики. Однак, намагаються досягти 6-годинної тривалості роботи, що приводить до збільшення площі колекторів і відповідно до погіршення економічних показників. Для того, щоб не збільшувати площу сонячних колекторів рекомендовано зробити систему, що відслідковуватиме рух Сонця при цьому змінюючи кут абсорбера сонячного колектора. Встановлено, що сонячні колектори, які змінюють кут абсорбера щомісяця отримують до $40 \%$ більше енергії відповідно. В праці вирішено важливе питання, едективності двох колекторів, що мають різну орієнтацію при різних кутах падіння інтенсивності сонячного випромінювання. Саме тому в роботі здійснено широкопараметричні дослідження їхніх теплотехнічних характеристик. Досліджено, що зміна азимутного кута а від $90^{\circ}$ до $60^{\circ}$, при $\varphi=90^{\circ}$, не суттево впливає на ефективність системи з сонячним колекторами, а подальше його відхилення суттєво - знижує. Також, встановлено, що одночасне відхилення кутів а та $\varphi$ призводить до суттевого зменшення використання падаючої інтенсивності сонячного випромінювання на сонячний колектор та едективності системи з сонячними колекторами загалом. Добове надходження сонячної радіації на поверхню колектора буде максимальним, коли не тільки кожний напрям при дискретній орієнтащії буде найкращим, але і час переорієнтації буде також оптимальним. В результаті теоретичних розрахунків отримано його середньорічну величину $\bar{K}_{\text {eff }}$, відповідно для різної кількості дискретних орієнтащій колектора $N$. Проведені дослідження роботи системи сонячного теплопостачання дискретної орієнтації сонячних колекторів дозволили обгрунтувати, що така система може більш ефективно використовувати сонячну енергію в ранішні та вечірні години.

Ключові слова: сонячна енергія, сонячна радіащія, сонячний колектор, дискретна орієнтація, температура теплоносія, теплопостачання.

Droblem statement. The total amount of solar energy received by the Earth's surface is 10,000 times that of global energy consumption [1]. It is established that $\approx 15 \%$ of all solar energy can be used without environmental damage. In addition, this amount of energy is equivalent to $7.7 \cdot 10^{12}$ tons of conventional fuel per year [2]. As a result, the supply of such a large amount of solar energy allows the solar energy industry to be a relevant area for research. At the same time, more and more installations are being developed to convert solar energy, which requires constant improvement due to the pace of development of solar energy [3; 4]. It is known that solar energy is converted into thermal energy, photovoltaic energy, and photobiological and chemical conversion of solar energy is also used. The efficiency of photobiological converters is estimated at $15 \%$, a chemical $-20-60 \%$ [5]. It is worth noting that photovoltaic collectors are used to providing electricity to space stations. [6]. The works [7;8] confirm the statement about the need for continuous improvement of existing solar collectors and the development of new ones. Moreover, according to the information Mega Trading Power Energy solar power plant Mohammed bin Rashid Al Maktoum in the southern desert of Dubai, it is the largest place for the installation of photovoltaic solar collectors, covering an area of $44 \mathrm{~km}^{2}$. Such the photovoltaic plant converts $1000 \mathrm{MW}$ per hour, which allows supplying electricity to $\approx 320$ thousand homes. However, today the electricity obtained from solar energy is quite variable, then by 2030 , it is expected to reduce its cost by $\approx 3$ times [9].

The global trend implies a significant increase in the use of renewable energy sources. The amount of solar energy in Ukraine received per unit area during the year is $1000-1350 \mathrm{kWh} / \mathrm{m}^{2}$. 
The optimal operating time of a flat solar collector is approximately 4 hours. However, they are trying to achieve a 6 -hour operating time, which leads to an increase in the area of collectors and, accordingly, to a deterioration in economic indicators. In order not to increase the area of solar collectors, it is recommended to make a system that will track the movement of the sun while changing the angle of the solar collector absorber. There is also the option with a fixed area of a certain shape, taking into account the change in the angle of incidence of the solar flow during the day.

Analysis of recent research and publications. A number of papers describe finding the optimal angle of inclination of the collector in order to establish the highest efficiency of the solar collector. Basically, such a change in the position of the collector is automated. It was found that solar collectors that change the angle of the absorber receive up to $40 \%$ more energy each month, respectively [10-12]. In addition, automatically changing the position of the solar collector is an expensive system, so in practice, they use changing the position of the solar collector seasonally manually [13-14].

The works claim that achieving the greatest efficiency is possible with the tilt of the solar collector $\pm 10^{\circ}$. Results of experiments on the influence of the azimuthal angle a showed that when $\alpha=0^{\circ}$ and $\alpha=22,5^{\circ}$ for latitudes up to $45^{\circ}$ the difference in relative annual exposure differs only by $2 \%$, and every $15^{\circ}$ the azimuthal angle causes a shift in the daily radiation distribution by about 1 hour towards the morning hours [15].

It is worth noting that in [16] a solar collector is proposed, the axis of which tilts to the horizon at an angle rationale for a given month of the year. This design allows you to get solar radiation equal to a constantly rotating collector and stationary. As a result, the analyzed works allow us to state that the efficiency of the collector will increase during the use of a design that has a system for tracking the movement of a non-permanent sunbeam.

Highlighting previously unsolved parts of a common problem. Summarizing the analyzed works, the actual and recommended task remains to evaluate the solar collector during its installation in a stationary position. Also, the issue of the efficiency of two collectors with different orientations at different angles of incidence of solar radiation intensity remains unresolved.

That is why in order to improve the heat supply of energy-efficient buildings with combined heat supply systems based on integrated solar collectors, it is necessary to carry out wide-parameter studies of their thermal engineering characteristics.

The purpose of this study. Since the correct installation of a stationary solar collector can give a significant gain in thermal energy during the period of operation, and this will affect the efficiency of the system as a whole and reduce the payback period.

Presentation of the main material. The experimental solar collector stand is stationary and contains two solar collectors for heat supply to an energy-efficient home. The experimental stand includes a heat storage tank, shut-off and control valves, and pipelines. A thermoelectric albedometer was used to measure total solar radiation. A thermoelectric actinometer is used to measure direct solar radiation. The temperature of the heat carrier and the external environment were measured using laboratory thermometers.

Experimental studies were conducted under the following conditions and simplifications:

- the intake of solar radiation to the collectors is assumed to be relative to the maximum;

- the expansion of the coolant was not taken into account;

- the stationary orientation of solar collectors with an optimal slope is accepted;

- 4 solar collector orientation variables are accepted;

- the measurements were carried out six times during the year;

- efficiency factor was averaged;

- the confidence probability of the experiment and approximation results is accepted $\alpha=0.95$;

- in the mathematical processing of the results continuous functional dependencies were assumed for discrete orientations.

The efficiency of a system with solar collectors is determined by the formula (1):

$$
\eta=Q_{\text {useful }} / Q_{\text {radiant }},
$$

where $Q_{\text {useful }}$ - amount of thermal energy, W, received by the battery tank during the experiment; $Q_{\text {radiant }}$ - the amount of radiant heat, W, emitted by the source per unit surface area of the solar collector absorber during the experiment.

$$
Q_{\text {radiant }}=A \cdot I \text {, }
$$

where $A$ - solar collector absorber area, $\mathrm{m}^{2}$; $I$ - intensity of solar radiation emitted by the source, $\mathrm{W} / \mathrm{m}^{2}$.

Amount of heat received by the battery tank $Q_{\text {useful }}$ it was determined using the balance equation of the thermal energy of the system.

Studied (Table 1) that the change in the azimuth angle a from $90^{\circ}$ to $60^{\circ}$, under $\varphi=90^{\circ}$, does not significantly affect the efficiency of a system with solar collectors, and its further deviation significantly reduces it.

Table 1

Solar collector efficiency $\eta$ under $\varphi=90^{\circ}$ and variable angle $a$

\begin{tabular}{|c|c|c|}
\hline № & $\mathbf{\alpha , ~}^{\mathbf{o}}$ & $\mathbf{n}$ \\
\hline 1 & 0 & 0 \\
\hline 2 & 20 & 0,2 \\
\hline 3 & 40 & 0,33 \\
\hline 4 & 60 & 0,36 \\
\hline 5 & 80 & 0,37 \\
\hline
\end{tabular}

Source: developed by the authors

It is also established that the simultaneous deviation of angles $\alpha$ and $\varphi$ leads to a significant reduction in the use of the incident intensity of solar radiation on the solar collector and the efficiency of the system with solar collectors in general.

It is worth noting that the best duration of operation of a solar collector is 4 hours. The proposed solar collector in the heat supply system is not an expensive design and does not require significant operating costs. However, it belongs to low-temperature solar collectors.

The daily intake of solar radiation to the collector surface will be maximum when not only each di- 


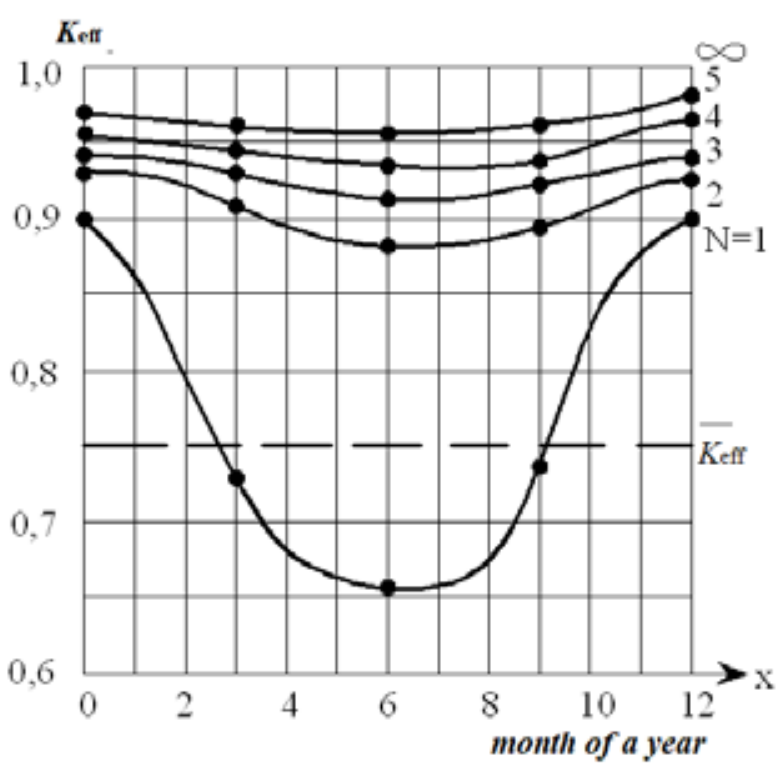

Figure 1. Annual change in the efficiency coefficient of discrete orientation methods Source: developed by the authors

rection with a discrete orientation will be the best, but the reorientation time will also be optimal.

Figure 1 shows the curves of solar radiation intake for all months of the year with different orientation options concerning the maximum possible radiation intake to the tracking orientation collectors (infractions). This ratio is the efficiency coefficient of the discrete orientation method $N$.

By approximating the curves in Figure 1 for a different number of orientations $\mathrm{N}$, the formulas are obtained (3)-(5):

$$
\begin{aligned}
& N=1: K_{\text {eff }}=0,66+(x-6)^{2} \cdot 0,010 ; \\
& N=2, K_{\text {eff }}=0,88+(x-6)^{2} \cdot 0,002 ;
\end{aligned}
$$

$$
\begin{aligned}
& N=3: K_{\text {eff }}=0,93+(x-6)^{2} \cdot 0,001 ; \\
& N=4, K_{\text {eff }}=0,95+(x-6)^{2} \cdot 0,001 ; \\
& N=5: K_{\text {eff }}=0,96+(x-6)^{2} \cdot 0,001,
\end{aligned}
$$

where $\mathrm{x}$ - this is the serial number of the month. Integrating the value of the efficiency coefficient $K_{\text {eff }}$ its average value is established. That is, the average value $\bar{K}_{\text {eff }}$ it was established by the method of approximation of curves and subsequent integration in the range from 0 to 12 . Therefore, if the areas of a curved trapezoid are equal $\left(\mathrm{S}_{1}=\int_{0}^{12} f_{i}(x) d x\right)$ and the corresponding rectangles $\left(\mathrm{S}_{2}=\bar{K}_{\text {eff }} 12\right)$ the average values were determined by:

$$
\bar{K}_{\text {eff }}=\frac{1}{12} \int_{0}^{12} f(x) d x
$$

As a result, its average annual value was obtained $\bar{K}_{e f f}$, accordingly for a different number of discrete collector orientations $N$.

Conclusion. A study of the operation of the solar collector in laboratory conditions was carried out since this allows setting and control all parameters that have a significant impact on experiments.

The dependences of the efficiency of the solar collector on the change in two angles of incidence of the heat flow, showing low efficiency of the solar collector with significant deviations of the angle of incidence of the heat flow on the collector heat receiver from the perpendicular, corresponding to the morning and evening hours of operation of the heat supply system, are established.

Conducting a study of the operation of the solar heat supply system of the discrete orientation of solar collectors allowed us to justify that such a system can use solar energy more efficiently in the morning and evening hours.

\section{References:}

1. Paranchych, S.Yu. (2002) Vidnovlyuval ni dzherela energiyi [Renewable energy sources]. Chernivci: Ruta. (in Ukrainian)

2. Misak, Y.S., Voznyak, O.T., Datsko, O.S., Shapoval, S.P. (2014) Solar energy: theory and practice. Lviv: Lviv Polytechnic Publishing House. (in Ukrainian)

3. Gladen, A.C., Davidson, J.H., Mantell, S.C. (2014) The effect of a thermotropic material on the optical efficiency and stagnation temperature of a polymer flat plate solar collector. J. Sol. Energy Eng, vol. 137, no. 2, 021003-021003. https://doi.org/10.1115/1.4028366

4. Doroshenko, A.V., Khalak, V.F. (2018) Solar polymer liquid collectors. Analysis of existing results, new solutions. Refrigeration Engineering and Technology, vol. 54, no. 5, pp. 44-52. https://doi.org/10.15673/ret.v54i5.1250 (in Ukrainian)

5. Paranchych, S.Yu. (2002) Vykorystannya energiyi soncya [Use of solar energy]. Chernivci: Ruta. (in Ukrainian)

6. Grilikhes, V.A. (1984) Solnechnaya energiya i kosmicheskie polity [Solar energy and space travel]. Moscow: Nauka. (in Russian)

7. Freris, L., Infield, D. (2008). Renewable Energy in Power Systems. UK: A John Wiley \& Sons.

8. Shapoval, S., Zhelykh, V., Spodyniuk, N., Dzeryn, O., \& Gulai, B. (2019) The effectiveness to use the distribution manifold in the construction of the solar wall for the conditions of circulation. Pollack Periodica, vol. 14, no. 2, pp. 143-154. doi:10.1556/606.2019.14.2.13

9. Babych, M., Krygul, R., Shapoval, S., Tolstushko, N., Korobka, S., \& Tolstushko, M. (2019) Results of experimental researches into process of oak veneer drying in the solar dryer. Eastern-European Journal of Enterprise Technologies, vol. 2(8-98), pp. 13-22. doi:10.15587/1729-4061.2019.162948

10. Khrustov, B.V., Avezov, P.P., Shafeyev, A.I. (1986) Energeticheski optimal'niy ugol naklona ploskikh kollektorov [Energy-optimized angle of inclination of flat collectors]. Geliotekhnika, vol. 5, pp. 51-55. (in Russian)

11. Kasperski, Ya., Lyevkovich, M., Pyetrovich, S. (2008). Kompaktnyj daxovyj kondycioner na sonyachnij energiyioptymizaciya kuta naxylu kolektoriv [Compact roof air conditioner on solar energy - optimization of the collectors angle]. Rynok instalyacij, vol. 5, pp. 8-11. (in Ukrainian)

12. Brugues, P.M. (1986) Utilizacion de la energia solar a baja temperatura por medio de captadores pianos. Instalador, vol. 21, pp. 33-41.

13. Gernomazu, D. (1989) Pat. 97101 N 125872. Romania. In-treprinderea de Retele Elektrice.

14. L'Esperance, P.M., Nikkei, R.D. (1988) U.S. Patent No. 4770162 N49860L. Phillips Petroleum Co.

15. Daffi, Dzh. A., Bekman, U.A. (Ed.). (1977) Teplovyye protsessy s ispol'zovaniyem solnechnoy energii [Thermal processes using solar energy]. Moscow: Mir. (in Russian) 
16. Satcunanatnan, S., Jolly, P., Persad, P. (1984) The desing and performance of semi-tracking flat-plate collectors, 8th Biln Congress International Solar Energy Socitty. Perth.

\section{Список літератури:}

1. Паранчич С.Ю. Відновлювальні джерела енергї. Чернівці : Рута, 2002.

2. Misak Y.S., Voznyak O.T., Datsko O.S., Shapoval S.P. Solar energy: theory and practice. Lviv : Lviv Polytechnic Publishing House, 2014.

3. Gladen A.C., Davidson J.H., Mantell S.C. The effect of a thermotropic material on the optical efficiency and stagnation temperature of a polymer flat plate solar collector. J. Sol. Energy Eng. 2014. Vol. 137, no. 2, 021003-021003. DOI: https://doi.org/10.1115/1.4028366

4. Doroshenko A.V., Khalak V.F. Solar polymer liquid collectors. Analysis of existing results, new solutions. Refrigeration Engineering and Technology. 2018. Vol. 54. No. 5. Pp. 44-52. DOI: https://doi.org/10.15673/ ret.v54i5.1250

5. Паранчич С.Ю. Використання енергії сонця. Чернівці : Рута, 2002.

6. Грилихес В.А. Солнечная энергия и космические полеты. Москва : Наука, 1984.

7. Freris L., Infield D. Renewable Energy in Power Systems. UK : A John Wiley \& Sons, 2008.

8. Shapoval S., Zhelykh V., Spodyniuk N., Dzeryn O., Gulai B. The effectiveness to use the distribution manifold in the construction of the solar wall for the conditions of circulation. Pollack Periodica. 2019. Vol. 14. No. 2. Pp. 143-154. DOI: 10.1556/606.2019.14.2.13

9. Babych M., Krygul R., Shapoval S., Tolstushko N., Korobka S., Tolstushko M. Results of experimental researches into process of oak veneer drying in the solar dryer. Eastern-European Journal of Enterprise Technologies. 2019. Vol. 2(8-98). Pp. 13-22. DOI: 10.15587/1729-4061.2019.162948

10. Хрустов Б.В., Авезов Р.Р., Шафеев А.И. Энергетически оптимальний угол наклона плоских коллекторов. Гелиотехника. 1986. № 5. С. 51-55.

11. Касперскі Я., Левковіч М., Петровіч С. Компактний даховий кондиціонер на сонячній енергії - оптимізація кута нахилу колекторів. Ринок інсталяцій. 2008. № 5. С. 8-11.

12. Brugues P.M. Utilizacion de la energia solar a baja temperatura por medio de captadores pianos. Instalador. 1986. Vol. 21. Pp. 33-41.

13. Gernomazu D. (1989). Пат. 97101 N 125872. Румунія. In-treprinderea de Retele Elektrice.

14. L'Esperance P.M., Nikkei R.D. (1988). U.S. Patent No. 4770162 N49860L. Phillips Petroleum Co.

15. Даффи Дж.А., Бекман У.А. Тепловые процессы с использованием солнечной энергии. Москва : Мир, 1977.

16. Satcunanatnan S., Jolly P., Persad P. The desing and performance of semi-tracking flat-plate collectors, 8th Biln Congress International Solar Energy Socitty. Perth, 1984. 